\title{
ANALISIS PERLAKUAN AKUNTANSI ATAS SELISIH KURS DAN TRANSAKSI DALAM MATA UANG ASING SERTA PENGARUHNYA TERHADAP LAPORAN KEUANGAN (STUDI KASUS PADA PT.APPIPA INDONESIA)
}

\author{
ANALYSIS OF ACCOUNTING TREATMENTS ON THE DIFFERENCE OF \\ EXCHANGE AND TRANSACTIONS IN FOREIGN EYES AND ITS EFFECT ON \\ FINANCIAL STATEMENTS \\ (CASE STUDY IN PT. APPIPA INDONESIA)
}

\author{
Rizki Eka Putra ${ }^{1}$ \\ ${ }^{I}$ (Akuntansi, Ekonomi, Universitas Riau Kepulauan, Indonesia \\ ${ }^{1}$ rizkiekaputra@gmail.com
}

\begin{abstract}
Abstrak
Studi kasus ini ditujukan untuk menganalisis penerapan perlakuan akuntansi atas selisih kurs dan transaksi dalam mata uang asing serta pengaruhnya terhadap laporan keuangan yaitu pada PT.Appipa Indonesia. Dalam transaksi pembelian (impor) dan transaksi penjualan (ekspor) antara dua negara yang berbeda, menggunakan mata uang asing dan melibatkan dua mata uang yaitu mata uang asing, dan mata uang lokal. Jika sebuah perusahaan melakukan transaksi menggunakan mata uang asing, maka akan menghasilkan keuntungan dan kerugian yang disebabkan oleh kurs nilai tukar antara dua mata uang. Keuntungan dan kerugian yang disebabkan oleh pertukaran nilai mata uang tersebut dicatat sebagai laba atau rugi selisih kurs yang dicatat terpisah dengan laba atau rugi operasional perusahaan. Transaksi dalam mata uang asing dan selisih kurs yang terjadi tidak akan berpengaruh secara signifikan terhadap laporan keuangan karena transaksi tersebut dicatat pada akun tersendiri sehingga berapapun nilainya akan memberikan informasi yang terpisah pada pengguna laporan keuangan. Perlakuan transaksi dalam mata uang asing pada PT.Appipa Indonesia yang sebagian besar dalam mata uang US Dolar sedangkan, mata uang pelaporan yang digunakan adalah mata uang rupiah telah berdasarkan pada PSAK No.10.
\end{abstract}

Kata Kunci ; Transaksi Dalam Mata Uang Asing, Selisih Kurs, Mata Uang Fungsional dan PSAK No.10.

\begin{abstract}
This case study aimed to analyze the application of accounting treatment on foreign exchange and foreign currency transactions and its effect on financial statements on PT.Appipa Indonesia. In a purchase transaction (imports) and sales transactions (exports) between two different countries, using foreign currencies and involves two currencies namely foreign currency and local currency. If a company conducts transactions in a foreign currency, it will generate profits and losses caused by the exchange rate between two currencies. Gains and losses caused by the exchange of the currency value recorded as gains or losses are recorded separately from the company's operating profit or loss. Transactions in foreign currency and exchange differences that occur will not significantly affect the financial statements because the transactions were recorded on a separate account so that any value will provide separate information on users of financial statements. The treatment of foreign currency transactions on PT.Appipa Indonesia are mostly denominated in US Dollars while, the reporting currency used is the rupiah currency has been based on PSAK No.10.
\end{abstract}


Keywords ; Foreign Currency Transactions, Foreign Exchange, Functional Currency and PSAK No.10

\section{PENDAHULUAN}

\section{Latar Belakang Masalah}

Pada perkembangan zaman saat ini dimana perindustrian semakin maju dan didukung dengan teknologi informasi dan komunikasi yang berkembang pesat sehingga terjadi persaingan yang ketat antara suatu perusahaan dengan perusahaan lain. Hal ini dapat menunjukkan perkembangan dunia usaha, sehingga memicu perusahaan-perusahaan untuk menjalin kerjasama yang baik dengan pihak asing atau pihak luar karena adanya persaingan harga dan ketersediaan barang yang tidak ditemukan di suatu negara. Seiring dengan perkembangan dunia usaha, perusahaan-peusahaan di Indonesia mulai memperluas usahanya. PT.Appipa Indonesia merupakan salah satu perusahaan swasta nasional yang bergerak pada bidang jasa penguliran pipa penunjang industri minyak dan gas bumi yang melakukan transaksi bisnis tidak hanya didalam negeri saja melainkan juga melakukan transaksi bisnis internasional seperti kegiatan ekspor dan impor karena adanya pasar luar negeri yang jauh lebih besar dan terbuka dibandingkan dengan pasar dalam negeri dalam perekonomian global.

Ekspor dan impor adalah dua sisi dalam perdagangan internasional. Dalam transaksi bisnis internasional diperlukan mata uang asing untuk penyelesaiannya dimana perubahan kurs atau nilai tukar mata uang merupakan salah satu faktor penting yang harus diperhatikan. Dalam melakukan transaksi antar negara yaitu dengan menggunakan mata uang asing yang berlaku secara global yang dapat diterima diberbagai negara.

Setiap transaksi yang terjadi dalam mata uang asing tersebut akan dicatat dalam perlakuan akuntansi yang diterapkan pada perusahaan. oleh sebab itu diperlukan perlakuan yang tepat dalam pengungkapan selisih kurs tersebut.

Pada perlakuan akuntansi atas mata uang asing terdapat perbedaan dari transaksi yang terjadi dalam mata uang yang berlaku disuatu negara atau yang dikenal dengan istilah mata uang fungsional. Terdapat hirarki indikator dalam penentuan suatu mata uang fungsional, jika hirarki indikator tersebut tidak dapat menentukan mata uang fungsional dengan jelas maka manajemen menggunakan pertimbangannya untuk menentukan mata uang fungsional yang paling tepat menggambarkan pengaruh ekonomi dari transaksi, kejadian dan kondisi yang mendasari. Perbedaan tersebut karena adanya selisih antara kurs mata uang asing terhadap kurs mata uang fungsional pada perusahaan tersebut.

Perlakuan akuntansi transaksi dalam mata uang asing cukup mempengaruhi laporan keuangan yaitu pada akun penjualan, pembelian, hutang, piutang dan lainnya. PT.Appipa Indonesia pernah mengalami penurunan nilai tukar rupiah terhadap dolar pada suatu transaksi pembayaran yang dilakukan pada saat impor material menggunakan US Dolar, sehingga mengalami kerugian selisih kurs yang cukup material.

Oleh karena itu, perlakuan akuntansi yang dilakukan harus sesuai dengan ketentuan yang berlaku secara umum yaitu perlakuan akuntansi yang mengacu pada Standar Akuntansi Keuangan (SAK) agar dapat dipergunakan oleh pihak-pihak yang berkepentingan sebagai bahan pertimbangan dalam pengambilan keputusan. Dalam hal perlakuan akuntansi atas selisih kurs ini yang digunakan sebagai acuan adalah Pernyataan Standar Akuntansi Keuangan (PSAK) No.10 tentang transaksi dalam mata uang asing, namun tidak semua perusahaan mengikuti ketentuan perlakuan akuntansi dalam transaksi mata uang asing yang berlaku secara umum. Apabila laporan keuangan atas mata uang asing masih digunakan tanpa penjelasan atas perubahan nilai dalam kondisi inflasi, maka akan mengakibatkan laporan keuangan yang sudah tidak relevan lagi bagi pengguna laporan keuangan. Atas dasar pemikiran tersebut penulis melakukan penelitian dengan judul "Analisis Perlakuan Akuntansi Atas Selisih Kurs dan Transaksi Dalam Mata Uang Asing Serta Pengaruhnya Terhadap Laporan Keuangan (Studi kasus pada PT.Appipa Indonesia)"

\section{Batasan Masalah}


Dalam penelitian ini penulis membatasi hanya dengan membahas tentang:

1. Perlakuan akuntansi atas selisih kurs yang diterapkan oleh PT.Appipa Indonesia dengan Pernyataan Standar Akuntansi Keuangan (PSAK No.10)

2. Perlakuan akuntansi atas transaksi dalam mata uang asing yang diterapkan oleh PT.Appipa Indonesia dengan Pernyataan Standar Akuntansi Keuangan (PSAK No. 10)

3. Pengaruh selisih kurs dan transaksi dalam mata uang asing terhadap penyajian laporan keuangan

\section{Rumusan Masalah}

Rumusan masalah yang akan dibahas adalah sebagai berikut:

1. Apakah terdapat perbedaan perlakuan akuntansi atas selisih kurs yang diterapkan oleh PT.Appipa Indonesia dengan Pernyataan Standar Akuntansi Keuangan (PSAK No.10)?

2. Apakah terdapat perbedaan perlakuan akuntansi atas transaksi dalam mata uang asing yang diterapkan oleh PT.Appipa Indonesia dengan Pernyataan Standar Akuntansi Keuangan (PSAK No.10) ?

3. Apakah selisih kurs dan transaksi dalam mata uang asing berpengaruh terhadap penyajian laporan keuangan?

\section{Tujuan Penelitian}

Tujuan penelitian yang ingin di capai adalah sebagai berikut:

1. Untuk mengetahui apakah terdapat perbedaan perlakuan akuntansi atas selisih kurs yang diterapkan oleh PT.Appipa Indonesia dengan Pernyataan Standar Akuntansi Keuangan (PSAK No.10).

2. Untuk mengetahui apakah terdapat perbedaan perlakuan akuntansi atas transaksi dalam mata uang asing yang diterapkan oleh PT.Appipa Indonesia dengan Pernyataan Standar Akuntansi Keuangan (PSAK No.10).

3. Untuk mengetahui apakah selisih kurs dan transaksi dalam mata uang asing berpengaruh terhadap penyajian laporan keuangan.

\section{Manfaat Penelitian}

Penelitian ini diharapkan dapat digunakan sebagai referensi bagi pihak-pihak yang terkait, pihak-pihak tersebut antara lain:

1. Bagi Penulis

Dapat menambah dan memperluas pengetahuan sebagai bekal dalam menerapkan ilmu yang telah diperoleh di bangku kuliah kedalam dunia kerja yang sesungguhnya.

2. Bagi Pembaca

Hasil penelitian dapat bermanfaat sebagai informasi dan referensi kepada yang membutuhkan dan juga sebagai tambahan ilmu pengetahuan bagi pembaca.

3. Bagi Perusahaan

Diharapkan hasil penelitian ini dapat dijadikan bahan referensi dan pertimbangan untuk melakukan perbaikan dalam penyajian laporan keuangan perusahaan, sehingga dapat memberikan informasi yang berharga bagi pengguna laporan keuangan dalam menyajikan laporan keuangannya dan perusahaan dalam pengelolaan laporan keuangan beserta segala kebijakan yang berkaitan langsung dengan aspek-aspek yang berhubungan dengan keuangan secara lebih baik.

4. Bagi Akademis

Hasil penelitian dapat bermanfaat sebagai informasi dan referensi dalam penyajian laporan keuangan, selain itu untuk mengetahui kualitas ataupun kemampuan mahasiswa dalam mengimplentasikan teori yang ditelitinya ke dalam dunia bisnis yang sebenarnya.

\section{Sistematika Penelitian}

Sistematika penulisan sebagai berikut:

Bab I. Pendahuluan

Bab II. Tinjauan Pustaka

Bab III. Metodologi Penelitian

Bab IV. Hasil Penelitian dan Pembahasan

Bab V. Kesimpulan dan Saran

TINJAUAN PUSTAKA

Landasan Teori

Laporan Keuangan

Pengertian Laporan Keuangan

Laporan keuangan pada Pernyataan Standar Akuntansi Keuangan (PSAK 1 Revisi 2013), 
dikemukakan bahwa laporan keuangan adalah suatu penyajian terstruktur dari posisi keuangan dan kinerja keuangan suatu entitas. Fahmi (2011:2) laporan keuangan yaitu merupakan suatu informasi yang menggambarkan kondisi keuangan suatu perusahaan dan lebih jauh informasi tersebut dapat dijadikan sebagai gambaran kinerja keuangan perusahaan tersebut.

Berdasarkan pengertian diatas dapat disimpulkan bahwa laporan keuangan merupakan suatu informasi yang menggambarkan kondisi keuangan suatu perusahaan dan informasi tersebut dapat dijadikan sebagai gambaran kinerja keuangan dari perusahaan tersebut.

\section{Tujuan Laporan Keuangan}

Laporan keuangan dimaksudkan untuk menyediakan informasi keuangan mengenai suatu badan usaha yang akan dipergunakan oleh pihak-pihak yang berkepentingan sebagai bahan pertimbangan didalam pengambilan keputusan ekonomi.

Tujuan laporan keuangan menurut Pernyataan Standar Akuntansi Keuangan (PSAK 1 Revisi 2013) yaitu memberikan informasi mengenai posisi keuangan, kinerja keuangan dan arus kas entitas yang bermanfaat bagi sebagian besar kalangan pengguna laporan dalam pembuatan keputusan ekonomi.

Sedangkan tujuan laporan keuangan menurut Fahmi (2011:28), tujuan utama dari laporan keuangan adalah memberikan informasi keuangan yang mencakup perubahan dari unsurunsur laporan keuangan yang ditujukan kepada pihak-pihak lain yang berkepentingan dalam menilai kinerja keuangan terhadap perusahaan disamping pihak manajemen perusahaan.

Tujuan dibuatnya laporan keuangan yang dikemukakan Martani,dkk (2012:33), tujuan laporan keuangan adalah menyediakan informasi yang menyangkut posisi keuangan, kinerja serta perubahan posisi keuangan yang bermanfaat bagi sebagian besar pemakai dalam pengambilan keputusan ekonomi.

Kegunaan dan Manfaat Laporan
Keuangan

Menurut Martani,dkk (2012:137), Adapun kegunaan laporan posisi keuangan yaitu:

1. Menganalis likuiditas yaitu seberapa cepat waktu yang diperlukan sampai suatu aset dapat terealisasi atau dikontrovesi menjadi kas atau sampai suatu liabilitas dapat terbayar.

2. Menilai solvabilitas yaitu kemampuan entitas membayar utangnya pada saat jatuh tempo.

3. Menilai fleksibilitas keuangan yaitu likuiditas dan solvabilitas akan menentukan fleksibilitas keuangan entitas, yaitu dengan mengukur kebutuhan dan peluang yang ada.

\section{Unsur-unsur Laporan Keuangan}

Menurut Pernyataan Standar Akuntansi Keuangan (PSAK 1 Revisi 2013), unsur laporan yang berkaitan secara langsung dengan pengukuran posisi keuangan adalah sebagai berikut:

1. Aset

2. Liabilitas

3. Ekuitas

\section{Jenis-jenis Laporan Keuangan}

Pada umumnya laporan keuangan terdiri atas tiga hal utama, yaitu neraca (Balance sheet), laporan laba rugi (Income statement) dan laporan perubahan modal (Statement of changes in capital). Dalam perkembangannya komponen laporan keuangan bertambah dengan satu laporan keuangan yaitu laporan arus kas (Cash flow). Sifat dan Keterbatasan Laporan Keuangan

Adapun keterbatasan laporan keuangan menurut Prinsip Akuntansi Indonesia (PAI) dalam Fahmi (2011:10) adalah sebagai berikut:

1. Laporan keuangan bersifat historis

2. Laporan keuangan bersifat umum dan bukan dimaksudkan untuk memenuhi kebutuhan pihak tertentu

3. Proses penyusunan laporan tidak terlepas dari penggunaan taksiran dan berbagai pertimbangan

4. Laporan keuangan lebih menekankan pada makna ekonomis 
suatu peristiwa dari pada bentuk hukumnya

\section{Pemakai Laporan Keuangan}

Menurut Martani,dkk (2012:33) para pemakai laporan keuangan antara lain:

1. Investor

2. Karyawan

3. Pemberi jaminan

4. Pemasok dan Kreditur usaha lain

5. Pelanggan

6. Pemerintah

7. Masyarakat

Nilai Tukar atau Kurs

Pengertian Nilai Tukar atau Kurs

Nilai tukar atau dikenal dengan kurs adalah sebuah perjanjian yang dikenal sebagai nilai tukar mata uang terhadap pembayaran saat ini atau dikemudian hari antara dua mata uang masingmasing negara atau wilayah.

Menurut peraturan Menteri Keuangan no.114/PMK.04/2007 pasal 1 yang dimaksud dengan nilai tukar adalah harga mata uang rupiah terhadap mata uang asing. Sedangkan menurut Imamul Arifin, Gina Hadi W (2009:82) nilai tukar adalah harga suatu mata uang yang diekspresikan terhadap mata uang lainnya.

Jenis-jenis Nilai Tukar atau Kurs

Berdasarkan kebijakan tingkat pengendalian nilai tukar mata uang yang diterapkan suatu negara, sistem mata uang secara umum dapat digolongkan menjadi:

1. Kurs tetap (Fixed Exchange Rate)

2. Kurs mengambang terkendali (Managed Floating Exchange Rate)

3. Kurs mengambang bebas (Free Floating Rate)

Kurs yang sering kita temui di Bank ataupun ditempat penukaran uang asing (Money changer) diantaranya sebagai berikut:

1. Kurs beli

2. Kurs jual

3. Kurs tengah

Faktor-faktor yang Mempengaruhi Nilai Tukar atau Kurs

Faktor yang mempengaruhi pergerakan nilai kurs biasanya merupakan akibat interaksi antara beberapa faktor secara simultan dengan mengansumsikan faktor lain yang tetap. Menurut Imamul Arifin, Gina Hadi W (2009:84-85) ada dua faktor penyebab perubahan nilai tukar, yaitu:

1. Faktor penyebab nilai tukar secara langsung, yaitu secara langsung permintaan dan penawaran valas

2. Faktor penyebab nilai tukar secara tidak langsung, yaitu adapun secara tidak langsung permintaan dan penawaran valas akan dipengaruhi oleh faktorfaktor berikut:

a. Aktivitas neraca pembayaran

b. Tingkat inflasi

c. Tingkat bunga

d. Tingkat pendapatan nasional

e. Kebijakan moneter

f. Ekspektasi dan Spekulasi

Faktor-faktor yang Mempengaruhi Pergerakan Nilai Tukar atau Kurs Mata Uang Suatu Negara

1. Perbedaan tingkat inflasi antar Negara

2. Perbedaan tingkat suku bunga antar Negara

3. Neraca perdagangan

4. Hutang publik (public debt)

5. Ratio harga ekspor dan impor

6. Kestabilan politik dan ekonomi

\section{Selisih Kurs}

Selisih kurs adalah selisih yang dihasilkan dari pelaporan jumlah unit mata uang asing yang sama dalam mata uang pelaporan pada kurs yang berbeda. Selisih kurs terjadi ketika terdapat perbedaan nilai tukar mata uang rupiah dengan mata uang asing yang mempengaruhi nilai kekayaan bersih

\section{Akuntansi Selisih Kurs dalam Standar Akuntansi Indonesia}

Pembukuan selisih kurs dalam SAK diatur dalam tiga standar dan satu interpretasi, yaitu PSAK 10, PSAK 11, PSAK 26 dan ISAK 4. Hal ini terjadi karena transaksi yang dapat menimbulkan selisih kurs mempunyai jenis dan tujuan yang berbeda-beda satu dengan lainnya.

\section{Mata Uang Asing}

Pengertian Mata Uang Asing

Menurut Jose Rizal Joesoef (2008:4), valuta asing adalah mata uang asing atau alat pembayaran luar negeri. 


\section{Bentuk Perdagangan Mata Uang Asing}

Menurut Haris Wibisono (2005), di dalam transaksi valuta asing terdapat beberapa bentuk transaksi yang sering terjadi.

Bentuk perdagangan atas foreign exchange terbagi menjadi tiga bentuk, yaitu:

1. Spot exchange

2. Foreign exchange

3. Swap

\section{Sistem Kurs Mata Uang Asing}

Di setiap negara memiliki suatu sistem kurs valuta asing yang biasanya ditentukan oleh kebijakan yang dianut oleh pemerintah di masing-masing negara.

terdapat tiga sistem kurs valuta asing yang dipakai suatu negara, yaitu:

1. Sistem kurs bebas (floating)

2. Sistem kurs tetap (fixed)

3. Sistem kurs terkontrol atau terkendali (controlled)

Jenis Perubahan Nilai Kurs Mata Uang Asing

Dalam melakukan transaksi dalam mata uang asing, nilai kurs mengalami perubahan setiap saat. Perubahan nilai kurs valuta asing umumnya berupa:

1. Apresiasi atau depresiasi

2. Devaluasi atau revaluasi

\section{Transaksi Dalam Mata Uang Asing}

Transaksi dalam mata uang asing adalah transaksi yang terjadi dengan menggunakan dua/lebih mata uang yang berbeda, dan memerlukan penyelesaian juga dalam mata uang yang berbeda pula.

Pada PSAK 10 (2010:10.1) menyatakan transaksi dalam valuta asing dapat terjadi dengan dua cara, yaitu: kegiatan usaha luar negeri (foreign operation) dan transaksi dengan menggunakan mata uang asing (foreign activities).

\section{Selisih Kurs Mata Uang Asing}

Transaksi yang menggunakan valuta asing membutuhkan nilai tukar atau kurs sebagai dasar perhitungan konversi ke mata uang fungsional perusahaan.

kurs valuta asing adalah rasio nilai pertukaran dua mata uang yaitu dari mata uang suatu negara terhadap negara lainnya. Pengertian lain yang dijabarkan mengenai selisih kurs menurut Standar Akuntansi Keuangan dalam PSAK 10 (2010:10.4) adalah "Selisih yang dihasilkan dari penjabaran sejumlah tertentu satu mata uang ke dalam mata uang lain pada kurs yang berbeda."

\section{Ekposur Nilai Tukar Mata Uang Asing}

Sebuah perusahaan bisnis dikatakan memiliki eksposur nilai tukar asing jika perubahan kurs mata uang asing mempengaruhi aliran kas operasi atau item dalam laporan keuangannya. Eksposur nilai tukar asing tersebut terbagi dua jenis yaitu accounting dan operating (economic) exposures (Tan, Lee, 2009:323).

Tujuan dan Ruang Lingkup Pernyataan Standar Akuntansi Keuangan No.10 (Revisi 2010)

\section{Tujuan PSAK No.10}

1. Suatu entitas dapat melakukan aktivitas yang menyangkut valuta asing dalam dua cara. Entitas mungkin memiliki transaksi dalam mata uang asing atau memiliki kegiatan usaha luar negeri.

2. Permasalahan utama adalah nilai tukar mana yang digunakan dan bagaimana melaporkan pengaruh dari perubahan nilai tukar dalam laporan keuangan.

\section{Ruang Lingkup PSAK No.10}

Pada Pernyataan Standar Akuntansi Keuangan (PSAK No.10) tentang pengaruh perubahan kurs valuta asing diterapkan pada:

1. Dalam akuntansi untuk transaksi dan saldo dalam mata uang asing, kecuali untuk transaksi-transaksi derivatif dan saldo yang ada dalam ruang lingkup PSAK 55 (revisi 2006): Instrumen Keuangan: Pengakuan dan Pengukuran

2. Dalam menjabarkan hasil dan posisi keuangan dari kegiatan usaha luar negeri yang termasuk dalam laporan keuangan konsolidasi entitas, konsolidasi secara proporsional atau metode ekuitas 
3. Dalam menjabarkan hasil dan posisi keuangan entitas kedalam suatu mata uang pelaporan.

\section{Penguraian Definisi}

Lingkungan ekonomi utama dimana sebuah entitas beroperasi adalah lingkungan dimana entitas tersebut utamanya menghasilkan dan mengeluarkan kas.

Pelaporan Transaksi Mata Uang Asing ke dalam Mata Uang Fungsional

Suatu transaksi mata uang asing adalah suatu transaksi yang didenominasikan atau memerlukan penyelesaian dalam suatu mata uang asing, termasuk transaksi-transaksi yang timbul ketika suatu entitas:

1. Membeli atau menjual barang atau jasa yang harganya didenominasikan dalam suatu mata uang asing.

2. Meminjam atau meminjamkan dana ketika jumlah yang merupakan utang atau tagihan didenominasikan dalam suatu mata uang asing.

3. Memperoleh atau melepas aset, atau mengadakan atau menyelesaikan kewajiban yang didenominasikan dalam suatu mata uang asing.

\section{Penggunaan Mata Uang Pelaporan Selain Mata Uang Fungsional}

Entitas dapat menyajikan laporan keuangannya dalam mata uang (atau beberapa mata uang) apapun. Jika mata uang penyajian berbeda dari mata uang fungsional entitas, entitas menjabarkan hasil dan posisi keuangannya ke dalam mata uang penyajian.

Pelepasan atau Pelepasan Sebagian dari Kegiatan Usaha Luar Negeri

Pada pelepasan pada suatu kegiatan usaha luar negeri, jumlah kumulatif dari selisih nilai tukar yang terkait dengan kegiatan usaha luar negeri, yang diakui di dalam pendapatan komprehensif lain dan diakumulasi ke dalam komponen terpisah dari ekuitas, harus dikelompokkan ulang dari ekuitas ke laba atau rugi (sebagai penyesuaian untuk pengelompokkan ulang) ketika keuntungan atau kerugian dari pelepasan suatu kegiatan usaha di luar negeri diakui.

\section{Pengaruh Pajak atas Semua Selisih Nilai Tukar}

Keuntungan atau kerugian pada transaksi mata uang asing dan selisih nilai tukar yang timbul pada penjabaran hasil dan posisi keuangan dari suatu entitas (termasuk suatu kegiatan usaha luar negeri) ke dalam suatu mata uang yang berbeda mungkin memiliki pengaruh pajak.

\section{Pengungkapan}

Suatu entitas mengungkapkan:

1. Jumlah dari selisih nilai tukar yang diakui dalam laba rugi kecuali untuk selisih nilai tukar yang timbul pada instrumen keuangan yang diukur pada nilai wajarnya melalui laba atau rugi sesuai dengan PSAK 55 (revisi 2006).

2. Selisih nilai tukar neto diakui dalam pendapatan kompre-hensif lain dan diakumulasikan dalam komponen ekuitas terpisah, dan juga harus mengungkapkan rekonsiliasi dari selisih nilai tukar tersebut pada awal dan akhir periode.

\section{Tanggal Efektif dan Ketentuan Transisi}

Entitas harus menerapkan Setiap goodwill yang timbul pada akuisisi suatu kegiatan usaha luar negeri dan setiap penyesuaian nilai wajar jumlah tercatat suatu aset dan kewajiban yang timbul pada akuisisi kegiatan usaha luar negeri tersebut harus diperlakukan sebagai aset dan kewajiban dari kegiatan usaha luar negeri secara prospektif untuk semua akuisisi yang terjadi setelah awal dari periode laporan keuangan di mana pernyataan ini pertama kali diterapkan.

Penerapan secara retrospektif setiap goodwill yang timbul pada akuisisi suatu kegiatan usaha luar negeri dan setiap penyesuaian nilai wajar jumlah tercatat suatu aset dan kewajiban yang timbul pada akuisisi kegiatan usaha luar negeri tersebut harus diperlakukan sebagai aset dan kewajiban dari kegiatan usaha luar negeri untuk akuisisi terdahulu diijinkan. 


\section{Penelitian Terdahulu}

Penelitian yang menguji hubungan penyajian laporan keuangan dengan berbagai fenomena akuntansi dan ekonomi telah banyak dilakukan, antara lain:

1. Penelitian yang telah menguji "Analisis Selisih Kurs dan Pengaruhnya Terhadap Laporan Laba Rugi Perusahaan" telah dilakukan oleh David HM Hasibuan dan Nopryannus pada tahun 2013.

2. Penelitian yang dilakukan oleh Dinar permata listyani pada tahun 2012, meneliti tentang "Analisis Penerapan PSAK No.10 (Revisi 2010) Pada Perusahaan Batu Bara".

\section{Kerangka Konseptual}

Adapun kerangka pemikiran sebagai landasan dalam mempermudah pemahaman terhadap pelaksanaan penelitian sebagai berikut:

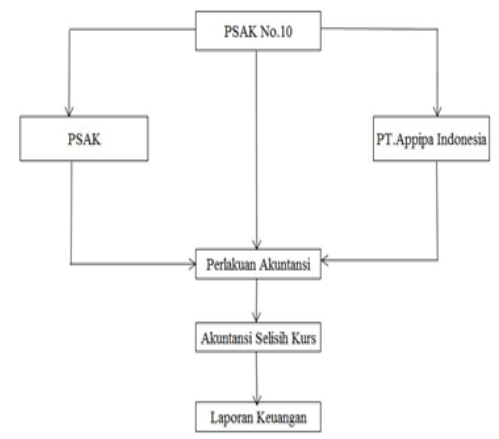

Kerangka konseptual

Gambar 2.1

\section{METODE PENELITIAN}

Objek Penelitian

Metode penelitian ini dipilih oleh peneliti untuk mengungkapkan penerapan, perlakuan akuntansi yang ada pada PT.Appipa Indonesia dengan Pernyataan Standar Akuntansi Keuangan (PSAK) yang berlaku.

Jenis penelitian yang digunakan adalah deskriptif kualitatif merupakan penelitian yang menghasilkan data deskriptif yang berupa kata kata tertulis atau lisan dari orang dan prilaku yang dapat diamati.

Tempat penelitian dilaksanakan pada PT.Appipa Indonesia yang berlokasi di Jl.Hang kesturi, Kawasan industri hock leong simpang Taiwan, Kabil, Batam.

\section{Waktu Penelitian}

Waktu yang dibutuhkan dalam proses penelitian, pengumpulan dan pengelolahan data yang diperlukan oleh peneliti adalah selama empat bulan, yaitu mulai tanggal 23 November sampai dengan selesai.

\section{Jenis dan Sumber Data}

Data yang akan digunakan peneliti merupakan sumber yang tidak langsung memberikan data kepada pengumpul data dan juga data-data yang bersumber dari hasil survei secara langsung melalui objek penelitian yaitu perlakuan akuntansi di PT. Appipa Indonesia.

\section{Teknik Pengumpulan Data}

Terdapat dua teknik yang digunakan peneliti dalam mengumpulkan data, yaitu sebagai berikut:

1. Tinjauan Pustaka

Dilakukan dengan membaca buku-buku, literatur, jurnal-jurnal, refrensi yang berhubungan dengan penelitian yang sedang dilakukan.

2. Penelitian Lapangan

Yaitu penelitian dan pengumpulan data secara langsung dilapangan dengan cara:

a. Wawancara (Interview)

Yaitu teknik pengumpulan data dengan berkomunikasi secara langsung pada objek penelitian yaitu Karyawan (bagian keuangan) PT. Appipa Indonesia.

b. Pengamatan (Observation)

Yaitu teknik pengumpulan data yang dilakukan peneliti dengan cara melakukan pengamatan secara langsung terhadap objek penelitian.

\section{Teknik Analisa Data}

Dalam penelitian ini data yang sudah terkumpul, diolah dan diinterprestasikan secara kualitatif dengan maksud menjawab masalah penelitian, data tersebut ditafsirkan menjadi kategori-kategori yang berarti menjadi bagian dari teori atau mendukung teori yang diformulasikan secara deskriptif

HASIL PENELITIAN DAN PEMBAHASAN 


\section{Gambaran Umum Perusahaan}

PT Appipa Indonesia merupakan salah satu perusahaan swasta nasional yang bergerak pada bidang jasa penguliran pipa penunjang industri minyak dan gas bumi. PT. Appipa Indonesia didirikan pada tahun 2006 berlokasi pada Jl. Hang Kesturi, Simpang Taiwan, Kawasan Industri Hock Leong, Kabil-Batam.

Sejak berdiri pada tahun 2006, PT.Appipa Indonesia telah melayani beberapa perusahaan dibidang industri minyak dan gas bumi. Setiap proses dilakukan dengan standar mutu yang telah ditetapkan, sehingga terjamin kualitas produk yang bertaraf internasional.

Visi Dan Misi Perusahaan

Visi

Sebagai perusahaan berkelas dunia yang terkemuka dan terpercaya dibidang manufaktur pertambangan minyak dan gas bumi. (As a well known and trusted world class organization in manufacturing oil and gas products.)

Misi

a. Memenuhi standar mutu, spesifikasi dan persyaratan pelanggan. (Fullfill the quality standard, customer's specification and requirements.

b. Mengembangkan kemampuan sumber daya manusia dibidang teknologi dan tanggung jawab. (Develop human resource skill in technology and responsibility.)

c. Peningkantan yang berkelanjutan pada kebijakan mutu, kesehatan, keselamatan dan lingkungan kerja. (ontinuous improvement on Quality' Health, Safety and Environment policy.)

\section{Strusktur Organisasi}

Berikut adalah bentuk struktur organisasi dari PT. Appipa Indonesia.

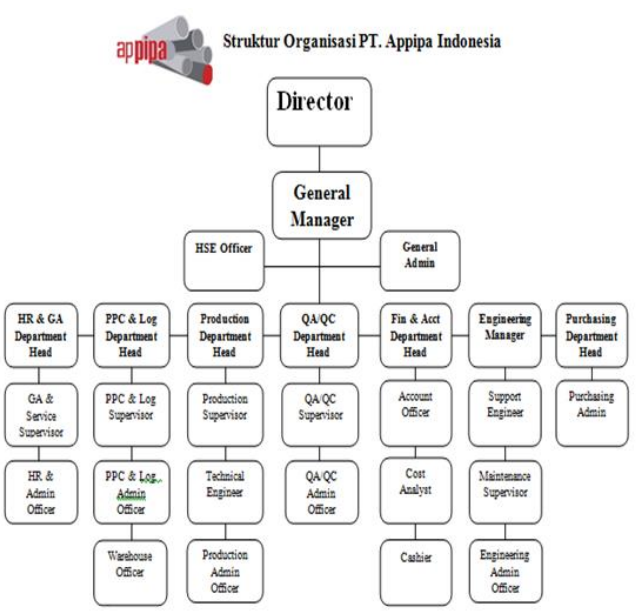

\section{Laporan Keuangan Perusahaan}

Mata uang pencatatan dan penyajian laporan keuangan PT.Appipa Indonesia sejak tahun pendirian sampai dengan akhir tahun 2015 adalah mata uang rupiah.

\section{Hasil Penelitian dan Pembahasan Penentuan Mata Uang Fungsional}

Manajemen PT.Appipa Indonesia melakukan pertimbangan dalam menentukan mata uang fungsional dengan memperhatikan hirarki indikator dalam penentuan suatu mata uang fungsional yang dijelaskan dalam PSAK No.10 (revisi 2010) tentang pengaruh perubahan kurs valuta asing.

Berikut ini faktor-faktor yang menjadi pertimbangan manajemen perusahaan dalam menentukan mata uang fungsional:

1. Mata uang yang paling mempengaruhi harga jual barang dan jasa Pendapatan utama PT.Appipa Indonesia dihasilkan dari transaksi jasa penguliran pipa, sejak PT.Appipa Indonesia didirikan pada tahun 2006 sampai dengan sekarang, jasa penguliran pipa tersebut mayoritas diekspor. Transaksi jasa penguliran menggunakan mata uang US Dolar, Singapur Dolar dan Rupiah yang sesuai kontrak perjanjian penjualan yang disepakati dengan konsumen.

2. Mata uang yang paling mempengaruhi biaya tenaga kerja dan biaya lain dari pengadaan barang atau jasa. Berikut ini adalah biaya-biaya yang terkait dengan beban pokok penjualan (cost of good sold) 
jasa penguliran pipa PT.Appipa Indonesia:
a. Biaya pokok produksi
b. Biaya sewa alat berat
c. Biaya pembelian material
d. Biaya gaji karyawan
e. Biaya pengangkutan
f. Biaya dokumen penjualan
g. Kalibrasi
h. Royalti

Dalam penentuan mata uang fungsional pada PT.Appipa Indonesia telah sesuai dengan PSAK No.10 yang berlaku.

\section{Penentuan Penggunaan Kurs}

Dalam pencatatan transaksi mata uang asing ( selain mata uang fungsional) perusahaan harus mempertimbangkan kurs yang akan digunakan. Kurs yang akan digunakan dalam pencatatan merupakan salah satu persiapan penting agar bagian akuntansi tidak berimprovisasi dalam penentuan penggunaan kurs.

PT.Appipa Indonesia menggunakan kurs pajak dalam melakukan pencatatan akuntansinya dan transaksi pajak, selisih kurs yang timbul atas perbedaan kurs antara mata uang asing dengan mata uang fungsional diakui sebagai laba atau rugi atas selisih kurs.

\section{Pencatatan Transaksi pada PT.Appipa Indonesia Berdasarkan Penerapan PSAK No.10 (revisi 2010)}

Pencatatan transaksi perusahaan dari awal pendirian hingga akhir tahun 2015 menggunakan mata uang rupiah. Perusahaan melakukan pencatatan dengan menggunakan mata uang yang sama dengan mata uang fungsional yaitu US Dolar. Hal tersebut sesuai dengan PSAK No.10 (revisi 2010) tentang pengaruh perubahan kurs valuta asing yang menjelaskan bahwa mata uang pencatatan disamakan dengan mata uang fungsional. Pencatatan transaksi dengan menggunakan mata uang fungsional memberikan manfaat bagi perusahaan yaitu dapat memperkecil nilai selisih kurs.

\section{Penentuan Mata Uang Pelaporan pada PT.Appipa Indonesia}

PT.Appipa menentukan mata uang penyajian dalam laporan keuangan tidak sama dengan mata uang fungsional, yaitu rupiah. Atas perbedaan antara mata uang pencatatan dan mata uang pelaporan tersebut, perusahaan harus melakukan proses translasi dengan menyajikan ulang mata uang yang digunakan dalam pencatatan transaksi yaitu US Dolar ke dalam mata uang penyajian laporan keuangan yaitu rupiah

Pelaporan Transaksi Mata Uang Asing ke dalam Mata Uang Fungsional

Berdasarkan PSAK No.10 (revisi 2010) tentang pengaruh perubahan kurs valuta asing, permasalahan utama dalam transaksi mata uang yang dicatat dalam mata uang fungsional antara lain adalah pada saat pengakuan awal transaksi mata uang asing, pelaporan pada akhir setiap periode pelaporan, pengakuan selisih kurs dan perubahan dalam mata uang fungsional

PSAK No.10 (revisi 2010) tentang pengaruh perubahan kurs valuta asing juga menjelaskan bahwa jika aset adalah aset nonmoneter dan diukur dalam mata uang asing, maka jumlah tercatatnya ditentukan dengan membandingkan Biaya perolehan atau jumlah tercatat dan Nilai realisasi neto atau jumlah yang terpulihkan

Pengaruh nilai yang terjadi atas perbandingan tersebut merupakan rugi penurunan nilai yang diakui dalam mata uang fungsional tetapi tidak akan diakui dalam mata uang asing atau sebaliknya.

\section{Pengukuran dan Penyajian Laporan Keuangan}

PT.Appipa Indonesia merupakan perusahaan yang memiliki mata uang fungsional Dolar amerika, maka untuk pencatatan PT.Appipa Indonesia diwajibkan untuk menggunakan Dolar amerika tersebut dalam proses pembuatan laporan keuangan, sementara PT.Appipa Indonesia ingin penyajian laporan keuangannya tetap dalam rupiah, maka PT.Appipa Indonesia melakukan translasi dari laporan keuangan Dolar amerika ke laporan keuangan rupiah. Seperti dijelaskan sebelumnya terdapat tiga jenis mata uang, yaitu mata uang pencatatan, fungsional dan pelaporan.

Perlakuan akuntansi pada selisih kurs atas transaksi dalam mata uang asing pada PT.Appipa Indonesia sudah diperlakukan sesuai dengan 
PSAK No.10 yaitu dengan dicatat sebagai laba atau rugi selisih kurs yang dicatat terpisah dengan laba atau rugi operasional perusahaan. Transaksi dalam mata uang asing dan selisih kurs yang terjadi tidak akan berpengaruh secara signifikan terhadap laporan keuangan karena transaksi tersebut dicatat pada akun tersendiri sehingga berapapun nilainya akan memberikan informasi yang terpisah pada pengguna laporan keuangan.

\section{KESIMPULAN DAN SARAN \\ Kesimpulan}

Berdasarkan hasil dari penelitian yang berjudul "Analisis Perlakuan Akuntansi Atas Selisih Kurs dan Transaksi Dalam Mata Uang Asing Serta Pengaruhnya terhadap Laporan Keuangan (Studi kasus pada PT.Appipa Indonesia)" yang telah dilakukan dapat disimpulkan bahwa manajemen PT.Appipa Indonesia dengan pertimbangannya melakukan penentuan mata uang fungsional berdasarkan PSAK yang berlaku. Berdasarkan hasil penelitian di PT. Appipa Indonesia peneliti memberikan kesimpulan sebagai berikut:

1. Perlakuan transaksi dalam mata uang asing pada PT.Appipa Indonesia yang sebagian besar dalam mata uang US Dolar sedangkan, mata uang pelaporan yang digunakan adalah mata uang rupiah telah berdasarkan pada PSAK No.10

2. Perlakuan akuntansi pada selisih kurs atas transaksi dalam mata uang asing pada PT.Appipa Indonesia sudah diperlakukan sesuai dengan PSAK No.10 yaitu dengan dicatat sebagai laba atau rugi selisih kurs yang dicatat terpisah dengan laba atau rugi operasional perusahaan

3. Transaksi dalam mata uang asing dan selisih kurs yang terjadi tidak akan berpengaruh terhadap laporan keuangan karena transaksi tersebut dicatat pada akun tersendiri sehingga berapapun nilainya akan memberikan informasi yang terpisah Saran pada pengguna laporan keuangan.

Berdasarkan hasil penelitian di PT. Appipa Indonesia peneliti dapat memberikan beberapa saran yang mungkin dapat berguna bagi perusahaan yakni:
1. PT.Appipa Indonesia dalam mendukung penerapan PSAK no.10 (revisi 2010) tentang pengaruh perubahan kurs valuta asing, perusahaan sebaiknya penentuan penggunaan kurs, PT.Appipa Indonesia dapat menggunakan kombinasi antara kurs pajak (KMK) dengan kurs Bank Indonesia (BI) karena jika hanya menggunakan kurs pajak saja maka, dirasakan kurang memperlihatkan fluktuasi perubahan kurs secara harian.

2. PT.Appipa Indonesia sebaiknya lebih memperhatikan peraturan-peraturan baru yang terkait dengan akuntansi maupun perpajakan agar perusahaan dapat menerapkan peraturan tersebut dalam perlakuan akuntansi lebih awal, sehingga dapat mengurangi kendala yang akan dihadapi perusahaan dalam melakukan peyusunan laporan keuangan

3. DSAK (Dewan Standar Akuntansi Keuangan) dalam menyusun PSAK (Pernyataan Standar Akuntansi Keuangan) sebagai dasar penyusunan laporan keuangan sebaiknya memperhatikan informasi-informasi dalam laporan keuangan yang dibutuhkan para pengguna.

DAFTAR PUSTAKA

Arifin, Imamul dan Hadi, Gina. 2009. Membuka Cakrawala Ekonomi. Bandung: Grafindo.

Beam. Anthony. Clement and Suzanne H.Lowensohn. 2009. Advanced Accounting Tenth Edition. Prentice Hall.

Brigham dan Houston. 2010. Dasar-dasar Manajemen Keuangan Buku 1 (Edisi 11). Jakarta: Salemba Empat.

Dwi, Martani., dkk. (2012). Akuntansi Keuangan Menengah Berbasis PSAK. Buku 1. Jakarta: Salemba Empat.

Fahmi, Irham. 2011. Analisis Laporan Keuangan (Edisi 1). Bandung: Alfabeta.

Gumanti, Tatang Ary. 2011. Manajemen Investasi Konsep, Teori dan Aplikasi. Jakarta: Mitra Wacana Media.

Ikatan Akuntan Indonesia. 2007. Pernyataan Standar Akuntansi Keuangan.Jakarta: Salemba Empat. 
Ikatan Akuntan Indonesia. 2010. Pengaruh Perubahan Kurs Valuta Asing. Jakarta: Institut Akuntan Publik.

Joesoef, Jose Rizal. 2008. Pasar Uang dan Pasar Valuta Asing. Jakarta: Salemba Empat.

Martono dan Agus Harjito.2010. Manajemen Keuangan (Edisi 3). Yogyakarta: Ekonisia

Menteri Keuangan. PMK Republik Indonesia No.114/PMK.04/2007 tentang nilai tukar adalah harga mata uang rupiah terhadap mata uang asing. Jakarta: Republik Indonesia,2007.

Menteri Keuangan. PMK Republik Indonesia No.24/PMK.11/2012 tambahan atas PMK No.196/PMK.03/2007. Jakarta: Republik Indonesia,2012.

Moleong, Lexy J. 2000. Metodologi Penelitian Kualitatif. Bandung: PT. Remaja Rosdakarya

Sinaga, Rosita Uli. Kajian Penerapan PSAK Tertentu yang Berlaku Efektif 2012 (PSAK 24, PSAK 10 dan ISAK 15). Jakarta: Institut Akuntan Publik Indonesia, 2011.

Sugiyono. 2010. Metode Penelitian Kuantitatif, Kualitatif dan RND. Bandung: Alfabeta.

Sukardi, David dan Kurniawan Indonanjaya. 2010. Manajemen Investasi Pendekatan Teknikal dan Fundamental untuk Analisis Saham (Edisi 1). Yogyakarta: Graha Ilmu.

Tan, Lee. 2009. Advanced Financial Accounting Updated Edition. Asia: Mc Graw-Hill Education.

Triyono. 2008. Analisis Perubahan Kurs Rupiah terhadap Dolar Amerika. Surakarta: Fakultas Ekonomi Universitas Muhammadiyah. 